Nordisk Tidsskrift for Kriminalvidenskab 2010

\title{
ISLAND, FINANSKRISEN OCH STRAFFRÄTT - I ETT FINLÄNDSKT PERSPEKTIV
}

Av PROFESSOR JUSSI TAPANI

This article explores the financial crisis in Iceland from a Finnish perspective. First, I provide a short introduction to the economic context of the Icelandic financial crisis and give a simplified overview of its primary causes. Second, I describe the primary features of the Finnish banking crisis as it stood at the end of the 1980s and beginning of the 1990s. Third, I present important discussions from criminal law, criminology and criminal policy that emerged during the banking crisis in Finland. These experiences can be useful in understanding and evaluating the types of challenges that the Icelandic criminal justice system is likely to face in the future. The current article serves as a starting point in a larger research project dealing with the complex relationship between financial systems, the criminal law and moral philosophy. *

\section{Inledning ${ }^{1}$}

Under de två senaste åren har vi varit tvungna att bevittna och uppleva den världsomfattande finanskrisens inflytande på enskilda länders nationalekonomi och enskilda medborgares levnadsförhållanden. Även om det finns allt tydligare tecken på ekonomisk tillväxt t.ex. i EU, tack vare det mäktiga lokomotivet Tyskland, hör man ändå regelbundet oroväckande nyheter från USA, vilka åstadkommer osäkerhet för världsekonomin. Därtill är det långt ifrån sannolikt att t.ex. Grekland, Portugal och Irland skulle ha kunnat klara av sina ekonomiska problem.

Globalt sett verkar det som om Island hör till de länder som redan har genomgått väldigt stora och tråkiga samt genomgripande förändringar på grund av finanskrisen. Dessa förändringar gäller såväl det politiska fältet, finanssektorns struktur som medborgarnas levnadsförhållanden. ${ }^{2}$ Därför är det föga överraskande att man har försökt leta efter svar på följande frågor: 1) vilka faktorer medverkade till krisen, 2) vad kunde göras för att förhindra liknande händelser i framtiden och 3) finns det personer som borde bära ansvaret och som till och med kunde ställas till straffrättsligt ansvar för de enorma ekonomiska skadorna? ${ }^{3}$

Det är förstås inte lätt att försöka besvara dessa omfattande frågor oberoende av om man utför en statligt organiserad utredning, som man gjorde på Island (se kapitel 2), eller om man behandlar dessa frågor som en artikelskribent. Därför

\footnotetext{
"Title in English: The Icelandic Financial Crisis from a Finnish Perspective. Original in Swedish.
} 
är jag tvungen att göra vissa begränsningar i denna artikel. Även om Islands finanskris utgör en utgångspunkt för min analys kommer jag att behandla temat ur ett finländskt perspektiv. Jag har aldrig varit på Island och vet ganska lite om vardagslivet på det krisdrabbade Island. Men det som kopplar ihop Island och Finland är vissa iögonfallande likheter mellan Islands finanskris och finanskrisen - eller snarare bankkrisen - i Finland i slutet av 1980-talet och början av 1990-talet. Därtill granskar jag dessa problematiska frågor främst ur straffrättsvetarens synvinkel eftersom jag inte är någon ekonom, sosiolog eller kriminolog. Trots dessa begränsningar är jag ganska övertygad om att de finska erfarenheterna och den samhällspolitiska diskussionen kring bankkrisens straffrättsliga anknytningspunkter möjligen kan hjälpa oss att bedöma huruvida straffrätten överhuvudtaget kan spela någon roll i sådana här finanskriser.

Jag inleder med att kortfattat redogöra för den isländska finanskrisens struktur och orsaker. Därefter kommer jag att behandla de finska erfarenheterna, dvs. den finska bankkrisens struktur och straffrättsliga reaktioner. Efter det diskuterar jag de svårigheter som uppstår då man försöker analysera finanskrisen ur en straffrättslig synvinkel.

\section{Kreppa dvs. finanskrisen som kontext}

\subsection{Utredningen}

Finanskrisen på Island nådde sin kulmen i oktober 2008 då tre stora bankerna, dvs. Glitnir Bank, Kaupthing Bank och Landsbanki Íslands rasade. ${ }^{4}$ Nästan exakt en månad tidigare, den 15 september, hade Lehman Brothers i USA fallit på knä på grund av den s.k. subprimekrisen. ${ }^{5}$ Väldigt snabbt uppstod en allmän uppfattning om att man ville ta reda på vad som egentligen hände på Island. Detta ledde till att Islands parlament, Althingi, tillsatte en utredningskommitté (The Special Investigation Commission, SIC) som hade i uppgift att utreda och analysera den process som ledde till sammanbrottet av de tre stora bankerna. Kommittén gav sin rapport den 12 april $2010 .^{6}$

Det verkar som en omöjlig uppgift att försöka hitta och konstruera plausibla förklaringar för en finanskris av den storlek och kvalitet som Island har varit tvungen att uppleva. I rapporten pekas dock på ett antal orsaker som har ansetts kanta den väg som ledde till finanskrisen. ${ }^{7}$ Dessa orsaker är kortfattat och förenklat beskrivna följande:

1) Bankernas utlåning till privatpersoner och företag på Island expanderade oerhört snabbt och tillväxten var ungefär $50 \%$ årligen från början av år 2004 till sammanbrottet år 2008. Detta berodde dels på privatiseringen och avregleringen av finanssektorn mellan åren 1991-2003, dels på ett ordentligt tillträde till den internationella finansmarknaden. Därtill fanns det incitament (uppmuntringar) som 
stimulerade tillväxten i bankerna. Problemet med incitament var att de största aktieägarna - som även blev de största gäldenärerna till respektive bank - hade relativt stort inflytande på hur man byggde upp dessa belöningsprogram i bankerna. En medverkande faktor var även den isländska statens och de isländska bankernas utmärkta kreditvärdighet. Finanssystemet växte sig allt för stort i förhållande till nationalekonomin; t.ex. i slutskedet av krisen, dvs. år 2008, motsvarade de tre största bankernas storlek nio gånger Islands BNP.

2) De största ägarna av bankerna blev de största gäldenärerna till respektive bank. Detta ledde till att bankerna försökte se till de största aktieägarnas intressen i stället för samtliga aktieägares intressen. I rapporten betonas speciellt rollen av Glitnir, som hyste stort intresse för sina största aktieägare, Baugur Group och FL Group. ${ }^{8}$ Dessutom har det ansetts att riskerna inte var tillräckligt diversifierade i finanssystemet, då gäldenärer och aktieägare utgjorde samma entiteter. Ett konkret exempel gäller stora isländska investeringsföretag som hade lånat pengar från utländska banker. Då dessa företag började ha ekonomiska svårigheter tog de "Tre Stora", dvs. Glitnir, Kaupthing och Landisbanki, ansvaret för finansieringen. De försökte med andra ord rädda de kunder som huvudsakligen även utgjorde de största aktieägarna inom dessa banker.

3) Banksystemet baserade sig i stort sett på krossinvesteringar och detta ansågs utgöra "ett systemfel" med stora inbakade risker. Ett konkret exempel på detta systemfel kan nämnas från år 2007, då priset på aktierna började sjunka. Bankerna beslutade att köpa egna aktier ( $45 \%$ av s.k. automatically matched trades) och försökte på så sätt påverka att priset på aktier inte sjönk för mycket.

4) Då den globala finanskrisen började uppvisa sina första tecken under sommaren 2007 var de isländska bankerna beroende av finansiering från den internationella lånemarknaden. Utlåningen till inhemska företag hade skett med utländsk valuta, men på grund av problem på den globala finansmarknaden började det så småningom vara brist på utländska pengar på Island år 2008..$^{9}$ Då finanskrisen spred sig vidare växte utlåningen till utländska partners. Det har antagits att bankerna tog emot kunder som inte hade kunnat få lån från andra banker utomlands. Därtill saknades det riskanalyser som kunde ha gjorts redan tidigare år 2008. Situationen blev ännu värre fast tecken på finanskrisen kunde ses redan år 2008, men isländska politiker gav utlåtanden av typen "stater garanterar banker", som inte baserade sig på riskanalyser. ${ }^{10}$

5) Central Bank av Island (senare $C B I$ ) utövade alltför försiktig finanspolitik. CBI lyfte räntan för långsamt från och med 2004 och den väntade även på politiskt styrda budjetåtgärder som aldrig togs i bruk. Därtill var cheferna och ekonomerna hos $\mathrm{CBI}$ oeniga om den rätta räntenivån. Dessutom reagerade $\mathrm{CBI}$ för sent då skuldsättningen snabbt började öka på Island. 
6) Kommunikationen mellan CBI och politiker misslyckades; t.ex. var mötena mellan centralbankens styrelse (the Board of Governors of the CBI) och ministrar egendomliga. Det fanns nämligen kommunikationssvårigheter i form av brist på skrivna dokument från $\mathrm{CBI}$ :s håll och brist på frågor från ministrarnas håll.

7) Kommunikationsvårigheterna gällde inte bara kommunikationen mellan CBI och politikerna, utan de centrala ministrarna (statsministern, näringsministern och finansministern) informerade inte heller övriga regeringsmedlemmar. ${ }^{11}$ Konstigt nog blev näringsministern, som var ansvarig för kontrollen av finanssektorn, inte kallad till de möten där statsministern, finansministern och utrikesministern träffade chefen för CBI.

8) Även myndigheterna underlät att vidta tillräckligt effektiva åtgärder i rätt tid. Detta gällde framför allt den centrala kontrollmyndigheten, dvs. the Financial Supervisory Authority (senare FME), som inte hade resurser att efterfölja och effektivisera kontrollverksamheten ${ }^{12}$ i takt med att bankverksamheten utvidgades. ${ }^{13}$ Ett konkret exempel gäller svårigheter vid analyseringen av information på grund av föråldrad datateknologi. Därtill har det ansetts att myndigheten inte vidtog tillräckligt hårda åtgärder vid lagbrott; revisionen var också bristfällig angående utlåningen till bankernas största kunder och bankernas köp av sina egna aktier.

\subsection{För stor tilltro?}

Det synes omöjligt att peka ut någon enskild faktor av de ovan nämnda som en grundläggande orsak till finanskrisen. Det är för lätt att skylla enbart på den offentliga makten, dvs. staten, som misslyckades med att sätta gränser för tillväxten och risktagandet, även om det inte går att förneka effekten av den djupgående privatiseringen och avregleringen av finanssektorn under 1990-talet. ${ }^{14}$ Men aktörernas girighet är också en alltför enkel förklaring. Det kunde dock hävdas, i enlighet med Margret Saemundsdóttir, att korruption, girighet och maktkamp utgör en del av förklaringarna till finanskrisen. ${ }^{15} \mathrm{Om}$ man då vänder blicken mot begreppet korruption - som givetvis är ett väldigt mångfasetterat begrepp och fenomen ${ }^{16}$ får vi kanske bättre fram det strukturella element, dvs. frågan om politikens och ekonomins sammanknytning, och de processer som påverkar beslutsfattandet $\mathrm{i}$ ett litet land.

Island hör utan tvivel till en kategori av länder som kan kallas mikrostater; det finns ungefär 320000 invånare på Island. Dessa länder kan man ofta beskriva som länder där "alla känner varandra". Då alla känner varandra åstadkommer detta i bästa fall förtroende mellan människor ${ }^{17}$ och vi är ofta vana vid att se tillit eller förtroende som något positivt. Såsom Tapio Lappi-Seppälä har poängterat har sådana länder ofta t.ex. lägre antal fångar och repressionsnivån är lägre. Detta har ansetts bero just på tillit. ${ }^{18} \AA$ andra sidan kan tillit leda till ett ökat beroende mellan 
aktörer: ju flera uppgifter en och samma person innehar i ett litet samfund desto större förväntningar kan riktas mot honom.

Vad som verkar vara ytterst viktigt i detta sammanhang är att den nya banksektorn utvecklades ur en gammal politisk struktur. Saemundsdóttir definierar det politiska systemet och banksektorn på Island som en koncentrerad kontrollstruktur i ett tätt samfund. Då är det endast naturligt att politiker hade stort inflytande på näringslivet och en stor önskan att skydda de som hörde till samma politiska och finansiella läger. ${ }^{19}$ Men den privatisering och avreglering som skedde under 1990-talet hade också lett till ett fenomen som Snorri Örn Árnason kallar för en intressekonflikt. $\AA$ ena sidan fick staten stora inkomster då finanssektorn växte men å andra sidan skaffade sig den nya ekonomins hjältar makt, och det politiska systemet förlorade den kontroll som flyttade sig till stora företag och finansiella institutioner. ${ }^{20}$

\section{Den finska bankkrisen och straffrätt}

\subsection{Bankkrisen ${ }^{21}$}

Det har påståtts att varje finanskris har sin egen struktur men samtidigt anses det finnas ett återkommande liknande mönster som var och en kris följer. ${ }^{22}$ En av de mest avgörande faktorerna anses vara en snabb tillväxt av utlåningen. Detta leder så småningom till att ekonomin blir upphetsad och euforisk: värdet på priser och egendom stiger, vinster blir större och kreditgivning till nya kunder öppnar nya möjligher. Samtidigt växer även risker angående olika lån på grund av överprissättning av tillgångar. I något skede uppnår slutligen värdeökningen sin gräns, marknadsaktörer börjar bli oroade och priset på egendom börjar gå ned. Detta leder ofta till en självmatande panikfas som kräver myndigheternas åtgärder.

Vad har detta mönster då att göra med den finska bankkris som bröt ut rejält $\mathrm{i}$ slutet av 1980-talet och i början av 1990-talet? Då man granskar vissa avgörande faktorer som påverkade krisens uppkomst kan man konstatera följande. ${ }^{23}$ För det första var det fråga om en djupgående avreglering av finansmarknaden från och med mitten av 80-talet. Tidigare hade det funnits en sträng ränteregleringen, som man beslöt att avreglera. Därefter hade bankerna bättre möjlighet att skaffa finansiering från den internationella kapitalmarknaden. Detta ledde till en snabb expansion av utlåning på den inhemska marknaden. Hushåll och företag blev även skuldsatta till utlandet. Ett konkret exempel gäller valutalån: antalet valutalån växte mellan åren 1987 och1990 från 30 miljarder mark till 100 miljarder mark. För det andra skedde dramatiska förändringar i realekonomin. Finlands ekonomi var sedan länge starkt beroende av bilateral handel med Sovjetunionen, men denna handel falnade tydligt i början av 1990-talet. Då dessutom finska politiker och ekonomiska beslutsfattare försvarade en stark valuta, fanns alla ingredienser för en riktig kris tillhanda. 
Jag vill absolut inte hävda att denna korta beskrivelse kan ge en tillräckligt detaljerad och omfattande bild av krisens orsaker. Detta är endast en förenkling. Men beskrivelsen innehåller två element som är av särskild vikt då vi reflekterar över bankkrisen i Finland och finanskrisen på Island. 1) Då man påbörjade avregleringen av finanssektorn i mitten av 1980-talet i Finland var regleringsstrukturen för bank- och finanssektorn totalt annorlunda jämfört med regleringsstrukturen på 1990-talet eller i början av 2000-talet på Island. Då man vill poängtera skillnader mellan dessa regleringsstrukturer kunde man använda begreppet regleringsgenerationer ${ }^{24}$ Avregleringen i Finland på 1980-talet skedde med andra ord i en relativt annorlunda politisk, ekonomisk och social kontext jämfört med 90-talet och 2000-talet på Island. 2) Därtill är det skäl att understryka relationen mellan realekonomi och finanssektorn. I Finland skedde enorma förändringar i realekonomin då den bilaterala handeln med Sovjetunionen tydligt falnade och exportindustrin råkade ut för ekonomiska svårigheter. Detta intensifierade vidare den negativa utvecklingen i Finland. Men på Island låg problemet just i finanssektorns storlek: den hade hunnit växa sig nio gånger större än BNP och finanssektorn var full av enorma risker.

\subsection{Straffrättsliga fenomen}

Jag har ovan försökt beskriva - dock förenklat - den ekonomiska kontext på Island och i Finland som är nödvändig för att kunna behandla vissa straffrättsligt betonade frågor. ${ }^{25}$ Då jag i det följande talar om straffrättsligt betonade frågor använder jag ordet i vid mening. Jag anser att de finska erfarenheterna av bankkrisen inte kan förstås om man glömmer bort den kriminologiska och kriminalpolitiska sidan av diskussionen.

Den straffrättsliga delen av diskussionen i Finland gäller främst de brottstyper som ansetts vara typiska för lagöverträdelser i samband med bankkrisen och som även har analyserats i straffrättsvetenskaplig forskning. Det är lätt att föreställa sig vilka möjligheter expansionen av utlåning erbjöd gärningsmän som ville utnyttja situationen. Därför är det föga överraskande att bedrägerier (SL 36:1) i olika konstellationer i affärslivet formar ett typiskt brott $i$ samband med ${ }^{26}$ sådana här kriser. Ett konkret och ofta uppträdande fall gäller låntagare som ger vilseledande information om sin betalningsförmåga. ${ }^{27}$ Och då bankerna konkurrerar om utlåningen måste man även ta risker och då behövs det ibland en kreativ tolkning av bestämmelser gällande kreditvärdigheten av potentiella kunder. Detta har lett till att bankdirektörer blev dömda för missbruk av förtroendeställning (SL 36:5). ${ }^{28}$

Skattebedrägeri och bokföringsbrott hör till den ekonomiska brottslighetens kärna och detta gäller utan tvivel även oredlighet som gäldenär (SL 39:1). Då den riktiga kraschen började i Finland i början av 1990-talet hamnade ett stort 
antal gäldenärer i svåra ekonomiska problem. Då försökte de t.ex. sälja företags egendom till underpris till ett företag som kunde fortsätta businessen och som ofta hörde till säljarens närmaste krets. Säljaren försatte sig genom dessa transaktioner på obestånd eller förvärrade väsentligt sitt obestånd.

I bankkrisens efterdyningar fick finländarna bevittna - dock inte helt oväntat men ändå överraskande - ett fall som gällde tagande av muta och brott mot tjänsteplikt (SL 40 kap.). Dåvarande minister Kauko Juhantalo försökte rädda sina egna företag genom att "koppla" ihop denna räddningsoperation (med hjälp av SKOPbanken) och en räddningsoperation av ett stort företag Tampella (med hjälp av statens medel). Fallet behandlades i riksrätten och Juhantalo dömdes.

Dessa exempel torde räcka för att visa att det ur straffrättsvetenskapens synvinkel är ytterst viktigt att systematisera och tolka de brottsbestämmelser som tillämpades på 1990-talet. Samtidigt kunde man även samla ihop olika slags material som gav oss empirisk information om typfall vid vissa ekobrott. Men det handlade ändå om rättsdogmatisk forskning kring bankkrisen.

Liksom i många andra länder finns det i Finland mycket flera rättsvetare än kriminologer och inte alls alla kriminologer sysslar med ekonomisk brottslighet. Då resurser är knappa måste man prioritera. Eftersom det på 1990-talet överlag behövdes information om den ekonomiska brottslighetens natur och omfång, ville man skaffa sig en helhetsbild av detta fenomen i den finska kriminologin. Ahti Laitinen med sina kolleger publicerade två undersökningar om ekonomisk brottslighet, ${ }^{29}$ men till bankkrisen anknuten brottslighet stod inte i särskild fokus i dessa undersökningar.

Det har dock gjorts forskning som givit oss närmare information om den finska bankkrisens mörka sida. Symptomatiskt nog har jurister med ett klart kriminologiskt kunskapsintresse varit intresserade av dessa frågor. Ari Huhtamäki publicerade redan år 1994 boken "Bankbrott”, som baserar sig på 100 rättsfall främst från tings- och hovrätter. Han medger själv att forskningen är metodologiskt rättsdogmatisk ${ }^{30}$ men oavsett detta ger den viktig information om bankbrottens gärningskontext, gärningstyper och gärningsmän som är av kriminologiskt värde.

Samma sak gäller även Kaisa Mäkeläs och Maija Hakmans undersökningar där de koncentrerat sig på konkursbrott, dvs. speciellt på oredlighet som gäldenär. ${ }^{31}$ Jag vill särskilt understryka Mäkelas forskning eftersom hon - liksom Hakman - som material utnyttjade hundra konkursfall där konkursförfarandet förföll på grund av att konkursboets medel inte räckte till för att betala kostnaderna för konkursförfarandet. De konkursfall som Mäkelä analyserade infaller i slutskedet av depressionen som har nära anknytning till bankkrisen i början av 1990-talet. Vad som är intressant i Mäkeläs forskning är grupperingen av konkurser. Av 100 
konkurser polisanmäldes 48 stycken och Mäkelä har indelat dessa fall enligt följande: 1) bokföringen var totalt försummad eller förlorad (10 fall), 2) spekulationen som ledde till konkurs var avsiktlig (14 fall), 3) man försökte rädda egendom eller ville förtvivlat fortsätta näringen (11 fall), 4) man var helt okunnig eller likgiltig (11 fall). ${ }^{32}$

$\mathrm{Nu}$ är skäl att poängtera en sak som gäller kriminologisk forskning och dess resultat i Finland. Fast det är nästan omöjligt att ge en exakt definition av kriminologi kan man säga att kriminologi är en interdisciplinär vetenskap. Under en rubrik samlas naturvetenskaplig, beteendevetenskaplig och samhällsvetenskaplig forskning rörande brottslighet och annat avvikande beteende, brottslingar och brottsbekämpning. ${ }^{33}$ Kriminologi analyserar med andra ord brott som samhälleliga fenomen. ${ }^{34}$ Och då närmar vi oss pudelns kärna. I synnerhet Anne Alvesalos undersökningar visar hur 1990-talet skapade ett momentum för ett stort antal åtgärder mot ekonomisk brottslighet. Dels är det fråga om bankkrisen och depressionen dels om empiriska resultat om den ekonomiska brottslighetens omfång och skador. Alvesalo har mångsidigt analyserat bland annat de samhälleliga processer som hade inverkan på vad som anses vara viktigt i ett samhälleligt beslutsfattande, vad som kan lyftas upp på agendan och vilka faktorer som inverkar förstärkande eller försvagande på dessa diskurser. ${ }^{35}$

Vad hände då i Finland på 1990-talet avseende kriminalpolitik? Kontrollen av ekonomisk brottslighet och grå ekonomi började effektiviseras genom fem på varandra följande bekämpningsprogram. ${ }^{36}$ Vid genomförandet av första och andra bekämpningsprogrammet på 1990-talet koncentrerade man sig främst på bekämpning av missbruk av offentlig intern och extern finansiering och på att förbättra sund konkurrens och verksamhetsvillkor i näringslivet (Statsrådets principbeslut [SRb] 1.2.1996; 22.10.1998).

De tre efterföljande programmen har godtagits på 2000-talet. Det tredje programmet var en fortsättning på två tidigare principbeslut tagna av regeringen, eftersom man kände att det behövdes för att upprätthålla ett tillräckligt ihärdigt och konsekvent bekämpningsarbete (SRb 20.6.2001). Det fjärde bekämpningsprogrammet godkändes 9.2.2006. I och med det realiseras åtgärder tagna i regeringsprogrammet, i programmet för den inre säkerheten bestyrkt av regeringen och i det inkomstpolitiska avtalet för bekämpning av ekobrott och svart ekonomi. Det sista programmet har godkänts 17.12.2009 och därigenom verkställs målet för bekämpning av grå ekonomi som ingår i regeringsprogrammet samt vidtas åtgärder enligt ställningstagandet under regeringens politiska överläggningar 24.2.2009 beträffande tryggandet av finansieringen av offentliga tjänster och förmåner.

Centrala teman i det sista programmet är vissa lagstiftningsåtgärder (en totalreform av förundersöknings-, tvångsmedels- och polislagen, som gäller all brotts- 
utredning och därför effektiverar också utredningen av ekonomiska brott), granskning av vissa myndigheters befogenheter som antas förbättra deras effektivitet och effektivisering av myndighetssamarbetet. Med hjälp av programmet försöker man även skapa förutsättningar för att upprätthålla en gemensam lägesbild för den ekonomiska brottsligheten.

Men detta är dock inte hela sanningen. Även om man med hjälp av bekämpningsprogrammen har nått relativt bra resultat, har man även mött avsevärda motgångar. ${ }^{37}$ Oron för den ekonomiska brottslighet som rådde i början av 1990-talet minskade något vid millennieskiftet och tecken på en minskad ekobrottsbekämpning visade sig både i den politiska och offentliga diskussionen som bland myndigheterna. I Finland påverkade det försvagade politiska intresset för ekobrottsbekämpning även verksamhetsvillkoren för ekobrottsutredningar. ${ }^{38}$ Därför måste man alltid vara försiktig när man drar slutsatser på basis av festtal och beslut: konkret arbete på gräsrotsnivån möter ofta svårare problem än vad som antagits vid beslutsfattandet.

\section{Vad för slags kontroll - eller mot vad?}

Om vi nu reflekterar över bankkrisens följder i Finland och finanskrisens följder på Island och resten av världen, märker man att tyngdpunkten i den offentliga debatten har satts på effektivisering av kontroll. T.ex. på EU-plan finns det olika slags förslag med syfte att bättre kunna kontrollera både de enskilda medlemstaternas ekonomi och banksektorns funktionsduglighet. Ett konkret exempel gäller bankernas s.k. stresstest som gjordes för att försöka återställa tilltron till finanssektorn. ${ }^{39}$ Fast man inte så mycket har diskuterat den möjliga relationen mellan finanskrisen och ekonomisk brottslighet i den offentliga debatten har man nog på Island presenterat dessa tankebanor. Árnason hänvisar just till de finska erfarenheterna på 1990-talet och konstaterar att det nu finns ett momentum på Island för att vidta åtgärder mot ekonomisk brottslighet. ${ }^{40}$

Men då måste vi fråga oss vad det egentligen är som vi vill kontrollera. Alla som har sysslat med ekonomisk brottslighet vet att diskussionen försvåras av begreppets flexibilitet. Kriminologer har med tiden presenterat många olika uppfattningar om det. Det räcker bara med att hänvisa till David Friedrichs bok där det presenteras ett antal element som påverkar vår uppfattning om vad som avses med ekonomisk brottslighet. ${ }^{41}$ I den finska ekobrottsbekämpningen har följande definition etablerat sig för begreppet ekonomisk brottslighet: "med ekobrott avses en straffbar gärning eller försummelse som strävar mot direkt eller indirekt ekonomiskt utnyttjande som sker i samband med verksamhet i företag, i offentlig sektor eller annan sammanslutning. I samband med verksamheten i företaget eller annan sammanslutning eller gärning som utnyttjar dem eller försummelse avses faktisk 
verksamhet eller förklädd som sådan, men ändå inte sådan verksamhet där man i gärningen endast använder företagets eller sammanslutningens namn eller verksamhet om inte verksamheten siktar på anmärkningsvärt direkta eller indirekta förmåner." 42

Den här definitionen tar endast implicit ställning till motivet bakom ekonomisk brottslighet, som kort sagt är strävan efter pengar. Då är det inte en lång väg till tanken att man skulle kunna uttnyttja teorin om rationella val (rational choice theory) i ekobrottsbekämpningen och kanske även i kriminologin. Och detta har man faktiskt även gjort i Finland - dock i ganska vid och lös mening. Det är alltså inte fråga om en sådan nytto-kostnads-kalkyl som man utnyttjar i ekonomin ${ }^{43}$ utan man har snarare modifierat teorin som ett perspektiv som hjälper till att förebygga ekonomisk brottslighet (situational crime prevention). ${ }^{44}$ Och även om man inte har velat urvattna teorin om rationella val har man varit tvungen räkna upp ett stort antal parametrar som antas förklara ekonomisk brottslighet. De kan delas upp på följande sätt: ${ }^{45}$ 1) formella sanktioner, 2) informella sanktioner, 3) förlust av självrespekt, 4) kostnader som beror på ett normenligt beteende, 4) konstnader som uppstår då man bryter regler, 5) moraliska hinder, 6) meningsfullhet av ett normenligt beteende, 7) brottets kontext dvs. företagskultur och 8) gärningsmannes förflutna.

Jag skall inte närmare behandla de problem som är anknutna till teorin om rationella val i sig. I stället vill jag lyfta fram vissa problem som verkar vara relevanta ifråga om den isländska finanskrisen om vi skulle vilja utnyttja teorin om rationella val i snävare eller bredare mening. För det första borde vi veta om vi är intresserade av individuella gärningar (företagsledarnas, bankdirektörernas eller politikernas beslut) eller även organisationsnivån, dvs. aktiebolag och bankernas verksamhet. Och hur ska vi förhålla oss till det statliga beslutsfattandet? Är det överhuvudtaget möjligt att tala om rationella val och om detta i princip är möjligt, vem eller vilka kan utpekas som rationella beslutsfattare?

För det andra behövs det vid sidan av denna "nivåproblematik" även en begreppslig precision då man analyserar och försöker förklara ekonomisk brottslighet (som kriminologiskt fenomen), brott (som juridiskt fenomen) och kontroll (som kriminalpolitiskt fenomen). ${ }^{46}$ Då man tänker på Islands finanskris ur straffrättsvetarens synvinkel verkar det som en självklarhet att det behövs forskning på flera olika nivåer. Eftersom ekonomisk brottslighet är ett väldigt komplext fenomen, borde man i kriminologisk forskning utreda vad som egentligen anses vara kännetecknande för den olagliga verksamheten ${ }^{47} \mathrm{i}$ denna kontext och om det finns teorier som kunde förklara de brott som begås i denna kontext. Därtill behövs det straffrättslig forskning som koncentrerar sig på systematisering och tolkning av de brottsbestämmelser som tillämpas i de rättegångar som i framtiden möjligen 
står framför den isländska åklagarmyndigheten och domstolarna. Men detta räcker inte. Dessutom skall man utreda hur man överhuvudtaget effektivt kunde samla in material i förundersökningar angående dessa händelser och på vilket sätt man hanterar de rättegånger där ansvarsfrågor avgöras.

Slutligen anser jag att det behövs även straffrättslig forskning där förbindelsen mellan ekonomisk brottslighet och moral ligger i fokus. Sett ur ett vidare perspektiv har man i samband med Islands finanskris konstaterat att man borde fästa avseende vid moraliska aspekter av arbetsprocesser inom finanssektorn och politiskt beslutsfattande. ${ }^{48}$ Straffrätt är dock alltid nära förknippad med filosofi och speciellt etik, dvs. moralfilosofi, men straffrätt, moralfilosofi och ekonomisk brottslighet tycks vara en sällsynt kombination. Stuart Greens arbete utgör dock ett klart undantag. Han analyser ekonomisk brottslighet ur en moralteoretisk synvinkel med hjälp av tre begrepp: skuld (mens rea), skada (harmfulness) och moralisk förkastlighet (moral wrongfulness).$^{49}$ Det som gör hans arbete intressant är hans begreppsapparatur. Han koncentrerar sig på brytandet av vissa moralregler som anses vara tillräckligt konkreta och som människorna kunde ha en gemensam uppfattning om. Han behandlar bedragande (cheating), vilseledande (deception), tvingande (coercion), utnyttjande (exploitation), oredlighet (disloyalty), brytande av ett löfte (promise-breaking) och olydnad (disobedience).$^{50}$ Enligt min mening kunde dessa begrepp erbjuda oss en viktig begreppsapparatur då vi vill analysera olika sidor av Islands finanskris.

\section{Litteratur}

Alhonsuo, S. \& Leinonen, H. (2008). Pankkikriisit noudattavat samaa kaavaaPankkikriisien yleisestä anatomiasta, Helsinki: BoF Online

2008, No. 16. Hittas i http://www.suomenpankki.fi/NR/rdonlyres/0840ED6AEC93-4CC9-AFC0-AA110D95FB1A/0/BoF_Online_16_2008.pdf (besökt 8.9.2010)

Alvesalo, A. (2003). The Dynamics of Economic Crime, Espoo: Poliisiammattikorkeakoulu.

Alvesalo, A. \& Virta, E. (2010). Den ekonomiska brottslighetens mönster i Finland, I Ystehede, P. J. (red.), Økonomisk kriminalitet nordiske perspektiver, Oslo: AiT e-dit AS, s. 29-52.

Anttila, I. \& Törnudd, P. (1983). Kriminologia ja kriminaalipolitiikka, Porvoo Helsinki - Juva: WSOY. 
Árnason, S. Ö. (2010). Economic Crime and Economic Crisis in Iceland: A moment for regulatory reform, I Ystehede, P. J. (red.), Økonomisk kriminalitet nordiske perspektiver, Oslo: AiT e-dit AS, s. 99-127.

Asp, P. \& Ulväng, M. \& Jareborg, N. (2010). Kriminalrättens grunder, Uppsala: Iustus Förlag.

Becker, G. (1968). Crime and Punishment: An Economic Approach, Journal of Political Economy 76, s. 169-217.

Black, W. K. (2010). Neo-classical Economic Theories, Methodology and Praxis Optimize Criminogenic Environments and Produce Recurrent, Intensifying Crises, Creighton Law Review, Hittas i SSRN: http://ssrn.com/abst$\underline{\text { ract }=1607124}$ (besökt 15.9.2010)

Chapter (2/2010). Report of the Special Investigation Commission (SIC), Hittas i http://sic.althingi.is/pdf/RNAvefKafli2Enska.pdf (besökt 30.8.2010)

Chapter (21/2010). Report of the Special Investigation Commission (SIC), Hittas i http://sic.althingi.is/pdf/RNAvefurKafli21Enska.pdf (besökt 30.8.2010)

Clarke, R. V. \& Cornish, B. (2001). Rational Choice, I verket Paternoster, R. \& Bachman, R. (eds.), Explaining Criminals and Crime. Essays in Contemporary Criminological Theory, Los Angeles: Roxbury, s. 23-42.

Ferguson, N. (2009). The Ascent of Money. A Financial History of the World, London: Penguin Books.

Green Paper. Corporate governance in financial institutions and remuneration policies. COM (2010) 284 final.

Green, S. P (2006). Lying, Cheating, and Stealing. A Moral Theory of White-Collar Crime, New York: Oxford University Press.

Friedrichs, D. (2007). Trusted Criminals. White Collar Crime in Contemporary Society, Third Edition, Belmont: Thomson Wadsworth.

Hakman, M. (1993). Sata konkurssia. Verotarkastuksiin ja asiantuntijahaastatteluihin perustuva tutkimus konkursseihin liittyvistä rikoksista, Helsinki: Oikeuspoliittinen tutkimuslaitos.

Hirvonen, M. \& Lith, P. \& Walden, R. (2010). Suomen kansainvälistyvä harmaa talous, Helsinki: Eduskunta, Hittas i http://web.eduskunta.fi/dman/Document. phx?documentId=so $17210161302877 \& \mathrm{cmd}=$ download (besökt 10.9.2010)

Jonung, L. \& Kiander, J. \& Vartia, P. (ed.) (2009). The Great Financial Crisis in Finland and Sweden - The Nordic Experiences of Financial Liberalization, Cheltenham: Edward Elgar.

Jännäri, K. (2009). Report on Banking Regulation and Supervision in Iceland: past, present and future, Reykjavik: Prime Minister's Office, Hittas i http:// eng.forsaetisraduneyti.is/media/frettir/KaarloJannari_2009.pdf (besökt 3.9.2010) 
Knuts, M. (2010). Kursmanipulation på värdepappersmarknaden, Helsinki: Suomalainen Lakimiesyhdistys.

Krugman, P. (2008). The Return of Depression Economics and the Crisis of 2008, London: Penguin Books.

Laitinen, A. \& Alvesalo, A. (1994). Talouden varjopuoli. Tutkimus talousrikosten vaikutuksista ja talousrikosoikeudenkäynneistä, Helsinki: sisäasiainministeriö.

Laitinen, A. \& Virta, E. (1998). Talousrikokset: teoria ja käytäntö, Espoo: Poliisiammattikorkeakoulu.

Langsted, L. B. (2010). Den retlige regulering af korruption i Norden, Nordisk Tidskrift for Kriminalvidenskap 97, s. 1-16.

Lappi-Seppälä, T. (2007). Tillit, välfärd och politisk ekonomi, Nordisk Tidskrift for Kriminalvidenskap 94, s. 399-429.

Mäkelä, K. (2001). Talouselämän rikokset, rikosoikeus ja kriminaalipolitiikka. Empiirinen ja rikosoikeusteoreettinen tutkimus rauenneista konkursseista, Helsinki: Suomalainen Lakimiesyhdistys.

Paternoster, R. \& Simpson, S. (1993). A Rational Choice Theory of Corporate Crime, I verket Clarke, R. V. \& Felson, M. (red.). Routine Activity and Rational Choice. New Brunswick: Transaction Publishers, s. 37-58.

Paternoster, R. \& Simpson, S. (1996). Sanctions Threats and Appeals to Morality: Testing a Rational Choice Model of Corporate Crime, Law \& Society Review 30, s. 549-583.

Ruuskanen, O. (2009). Pankkikriisi ja rahoitusmarkkinoiden sääntely, Joensuu: Joensuun yliopisto 2009. Hittas i http://joypub.joensuu.fi/publications/dissertations/ruuskanen pankkikriisi/ruuskanen.pdf (besökt 8.9.2010)

Saemundsdóttir, M. (2010). Sosioøkonomiske kjennetegn på den islanske politikken og bankstruktur, Nordisk Tidskrift for Kriminalvidenskap 97, s. 29-40.

Sigmundsdóttir, A. (2010). Ihmisen aiheuttama katastrofi, i Kreppa. Islannin kriisin opetukset, Loimaa: Newprint s. 6-16.

Tapani, J. (2004). Petos liikesuhteessa. Talousrikosoikeudellinen tutkimus, Helsinki: Suomalainen Lakimiesyhdistys.

Tett, G. (2010). Fool's Gold. How Unrestrained Greed Corrupted a Dream, Shattered Global Markets and Unleashed a Catastrophe, London: Abacus.

Tähtivuori, R. (1999). Pankinjohtajan rikos- ja vahingonkorvausvastuu luottotappioista, Oikeustiede-Jurisprudentia XXXII, s. 373-460.

Working group on Ethics (2010). The main conclusion of the Working group on Ethics, Hittas i http://sic.althingi.is/pdf/WorkingGroupOnEthics_Summary. pdf (besökt 15.9.2010) 


\section{Notes:}

1 Jag tackar assistenten Dan Helenius för språklig granskning av texten och juris doktor, advokaten Mårten Knuts för värdefulla kommentarer och för språkliga synpunkter.

2 Se Sigmundsdóttir (2010) och hennes blogsida www.icelandweaterreport.com. Det är skäl att poängtera att hon detta år har publicerat boken Living Inside the Meltdown där finanskrisen och dess följder beskrivs ur medborgarnas, dvs. vanliga människornas, synvinkel.

3 Magnússon (2010) ger en god helhetsbild av de svårigheter som har uppstått då myndigheter påbörjade förundersökningar kring finanskrisen.

4 Staten tog över Glitnir 7.10.2008, Landsbanki 7.10.2008 och Kaupthing Bank 9.10.2008.

5 Se närmare om subprimekrisen och dess följder t.ex. Tett (2010) och Krugman (2008), speciellt s. 165-180. Se även Ferguson (2009) som granskar utvecklingen ur ett bredare historiskt perspektiv.

6 Vissa delar av rapporten har översatts till engelska. Se framför allt Chapter (2/2010) och Chapter $(21 / 2010)$

7 Chapter (2/2010) s. 1-18. Se utförligare analysen i Chapter (21/2010).

8 Chapter $(21 / 2010)$ s. $6-7$.

9 Chapter $(21 / 2010)$ s. 56.

10 Se närmare Chapter (21/2010) s. 135-136.

11 I rapporten (Chapter [21/2010] s. 146-147 och s. 155-158) utpekas statsministern som den huvudansvarige: från och med 7.2.2008 borde han ha vidtagit tillräckligt kraftiga åtgärder, till och med lagstiftningsåtgärder, för att minska banksystemets storlek och volym på Island. Andra ansvariga ansågs vara finansministern och näringsministern samt chefen för FME och centralbankens chefer (the Board of Governors of the CBI).

12 Se närmare Jännäri (2009) som har analyserat kontrollmekanismen på Island.

13 Se även Árnason (2010) s. 104-105 om företagskulturen som uppstår då strukturella förändringar är snabba i ekonomin och s. 108 om FME.

14 Se Árnason (2010) s. 102-103 med ytterligare hänvisningar.

15 Saemundsdóttir (2010) s. 29-40.

16 Se t.ex. Langsted (2010) s. 1-16.

17 Saemundsdóttir (2010) s. 32.

18 Lappi-Seppälä (2007) s. 399-429.

19 Saemundsdóttir (2010) s. 37.

20 Se Árnason (2010) s. 103.

21 Ibland talar man om sparbankskrisen, eftersom sparbankerna var de hårdast drabbade bankerna $\mathrm{i}$ Finland. Se Huhtamäki (1994) s. 6.

22 Alhonsuo \& Leinonen (2008).

23 En viktig och mångsidig analys av finanskrisens orsaker och erfarenheter presenteras av artiklar som ingår i verket Jonung \& Kiander \& Vartia (2009). Se också Ruuskanen (2009) s. 69-131 och redan Huhtamäki (1994) s. 13-21.

24 Så t.ex. Ruuskanen (2009).

25 Knuts (2010) s. 27-61 visar på ett konkret och utmärkt sätt varför kontextualiseringen är så viktigt i straffrättsvetenskap - och överhuvudtaget i rättsvetenskap. Detta gäller framför allt sådana komplexa omgivningar som värdepappersmarknaden.

26 Jag använder begreppet "i samband med sådana här kriser", eftersom det är ytterst besvärligt att säga exakt, i vilket skede gärningsmän egentligen hade information som kunde utnyttjas i sådana här "finansbubblor". Problemet med analyseringen av ett ex ante och ex post -perspektiv måste lämnas här åt sidan.

27 Se närmare Tapani (2004).

28 Tähtivuori (1999). 
29 Se främst Laitinen \& Alvesalo 1994 och Laitinen \& Virta 1998.

30 Huhtamäki (1994) s. 33.

31 Mäkelä (2001); Hakman (1993).

32 Mäkelä (2001) s. 77-91. Hakman har nästan en likadan gruppering (s. 106 och 147) men i hennes undersökning polisanmäldes endast 21 konkursfall.

33 Asp \& Ulväng \& Jareborg (2010) s. 21.

34 Anttila \& Törnudd (1983) s. 15.

35 Se Alvesalo (2003).

36 Se närmare Alvesalo \& Virta (2010) som ger en översikt av de mest akuta problemen i den ekonomiska brottslighetens mönster i Finland. Därtill är det skäl att poängtera att sommaren 2010 publicerades en undersökning av Hirvonen \& Lith \& Walden (2010) som handlar om Finlands internationaliserade gråa ekonomi. Man bör dock minnas att ekonomisk brottslighet och grå ekonomi inte är identiska begrepp.

37 Alvesalo \& Virta (2010) s. 33.

38 Se närmare Alvesalo (2003).

39 Se även COM (2010) 284 final.

40 Se Árnason (2010) s. 117-119.

41 Friedrichs (2007) s. 4-8 som bland annat understryker behovet av att analysera begreppet på tre olika nivåer: på en polemisk, typologisk och operationell nivå.

42 Översättningen till svenska hittas i Alvesalo \& Virta (2010) s. 33.

43 Se t.ex. Becker (1968) som anses höra till de som ordentligt tog in brottets ekonomi i den ekonomiska begreppsbildningen.

44 Se framför allt Clarke \& Cornish (2001) s. 23-42.

45 Paternoster \& Simpson (1996) s. 555-556 och Paternoster \& Simpson (1993) s. s. 40-53.

46 Så även Friedrichs (2007) s. 222.

47 Personligen har jag svårt att hävda att finanskrisen på Island i kriminologisk mening kunde förklaras med hjälp av s.k. kriminogeniska tankesätt. Se om detta angående subprimekrisen i USA t.ex. Black (2010).

48 Working group on Ethics (2010).

49 Green (2006) s. 31-33, 34-39 och 39-47.

50 Se närmare Green (2006) s. 45 där han argumenterar för sitt val av just dessa moralregler.

Adress:

Juridiska Fakulteten

20014 ÅBO UNIVERSITET

Finland

E-post: jussi.tapani@utu.fi 